\title{
CONTENTS - SEPTEMBER
}

XXXVII. Wallace Stevens: The Life of the Imagination. By

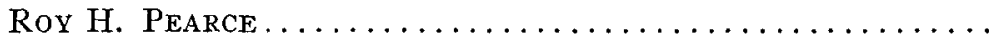

XXXVIII. Lawrence's Collected Poems: The Demon Takes Over. By Phyllis Bartlett............................ 583

XXXIX. New Letters from Mrs. Browning to Isa Blagden. By EDWARD C. MCAlEER .............................. 594

XL. Melville and the Midwest. By Jorn W. Nichol........ 613

XLI. Pierre Bayle and Moby Dick. By Mrldicent Bell..... 626

XLII. Henry Norman Hudson and the Whig Use of Shakespeare. By John StAfFord...........................

XLIII. Tennyson's Development during the "Ten Years' Silence" (1832-1842). By Joyce Green................. 662

XLIV. The Structure of Rasselas. By Gwin J. KoLB........ 698

XLV. Candide's Garden. By William F. Bottiglia........ 718

XLVI. Swift's View of the Dutch. By ElLen Douglass Leyburn 734

XLVII. New Light on the Antídoto against Gongora's "Pestilent" Soledades. By Eunice Joiner Gates.....................

XLVIII. "Or Else This Were a Savage Spectacle." By Brents StIRLING................................... 765

XLIX. Measure for Measure and Elizabethan Comedy. By

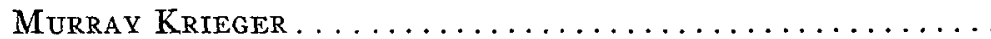

L. Giraldi's Hecatommithi, Deca II, 1: Central Version in the Diffusion of the Courtly Cid Theme. By Joseph G. Fucilla

LI. The Meaning of Bonaventure Des Périers' Cymbalum Mundi. By Wolfgang Spitzer . . . . . . . . . . . . . . . . . . .

LII. The Plan of the Canterbury Pilgrimage. By Chardes A. OWEN, JR

LIII. The Biblical Characters of Chaucer's Monk. By DudLEy

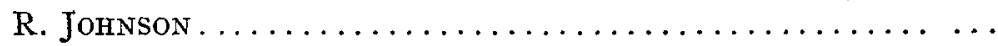

LIV. The Relationship of the Old English Andreas to Beozoulf. By Leonard J. Peters................................

LV. The Physiological Interpretation of Sound Spectrograms. By Pierre Delattre.......................... 864

Acts of the Executive Council..................... 876 


\section{FORTHCOMING}

\section{IN DECEMBER:}

The Genesis of Beownlf: A Caveat.... The Order of the Canterbury Tales.... The Tournaments of Tottenham and Lappenhausen.... The Shipwreck of Don Manuel de Sousa in the Spanish Theater.... Doctor Faustus: A Case of Conscience. ... Hamlet's Apostrophe on Man: Clue to the Tragedy.... Shakespeare's "Singing Man of Windsor." ... Herbert's Form.... Milton and Critical Re-estimates.... The Historical Criticism of Milton.... An Unpublished MS. by La Fontaine... Time, Space, and Symbol in Iphigénie... Pope and "the Weighty Bullion of Dr. Donne's Satires." . . Gray's Elegy: The Biographical Problem in Literary Criticism... . The Beginnings of the Study of Synonyms in England. . . Renan's Revision of his Libertê de penser Articles.... Dickens the Paymaster.... "Dover Beach" and "Say Not the Struggle Nought Availeth." ... The Nigger of the "Narcissus": A Re-examination.... The Inadequate Vulgarity of Henry James. ... Pygmalion: Bernard Shaw's Dramatic Theory and Practice.

\section{IN MARCH:}

Goethes Phantasiearbeit am Fauststoff im Jahre 1771....W. D. Howells' Defense of the Romance. ... The Self-conscious Narrator in Comic Fiction before Tristram Shandy.... David Garrick and The Clandestine Marriage. ... Astronomical Dating for Some of Lydgate's Poems.... Shelley and Malthus.... The Spirit of the Times and a "New Work by Boz." . . The Athelstan Gift Story: Its Influence on English Chronicles and Carolingian Romances.... Ruskin and Hobson. ... The Immediate Source of The Dynasts... . The Fleshly Controversy.... The Contributions of John Nichols to Boswell's Life of Johnson. . . . Charles Lamb's Insight into the Nature of the Novel. . . . Structure and Design in Wernher's Meir Helmbrecht.... A Jester at the Grail Castle in Wolfram's Parzival.... Coleridge and the Wheels of Intellect. . . . Le Temps chez Apollinaire. ... 